Grout and Vitrification Formula Development

$$
\text { CONF-970962-- }
$$

for Immobilization of Hazardous Radioactive Tank Sludges at ORNL

T. Michael Gilliam and Roger D. Spence

Oak Ridge National Laboratory

P.O. Box 2008

Oak Ridge, Tennessee 37831-6202

Originally Prepared for Presentation

at the Las Vegas, Nevada, American Chemical Society National Meeting

Symposium on "Science and Technology for Disposal of Radioactive Tank Wastes"

September 8-12, 1997

Subsequently Accepted for Publication

by Plenum Publishing Corporation

233 Spring Street

New York, New York 10013-1578

April 1998
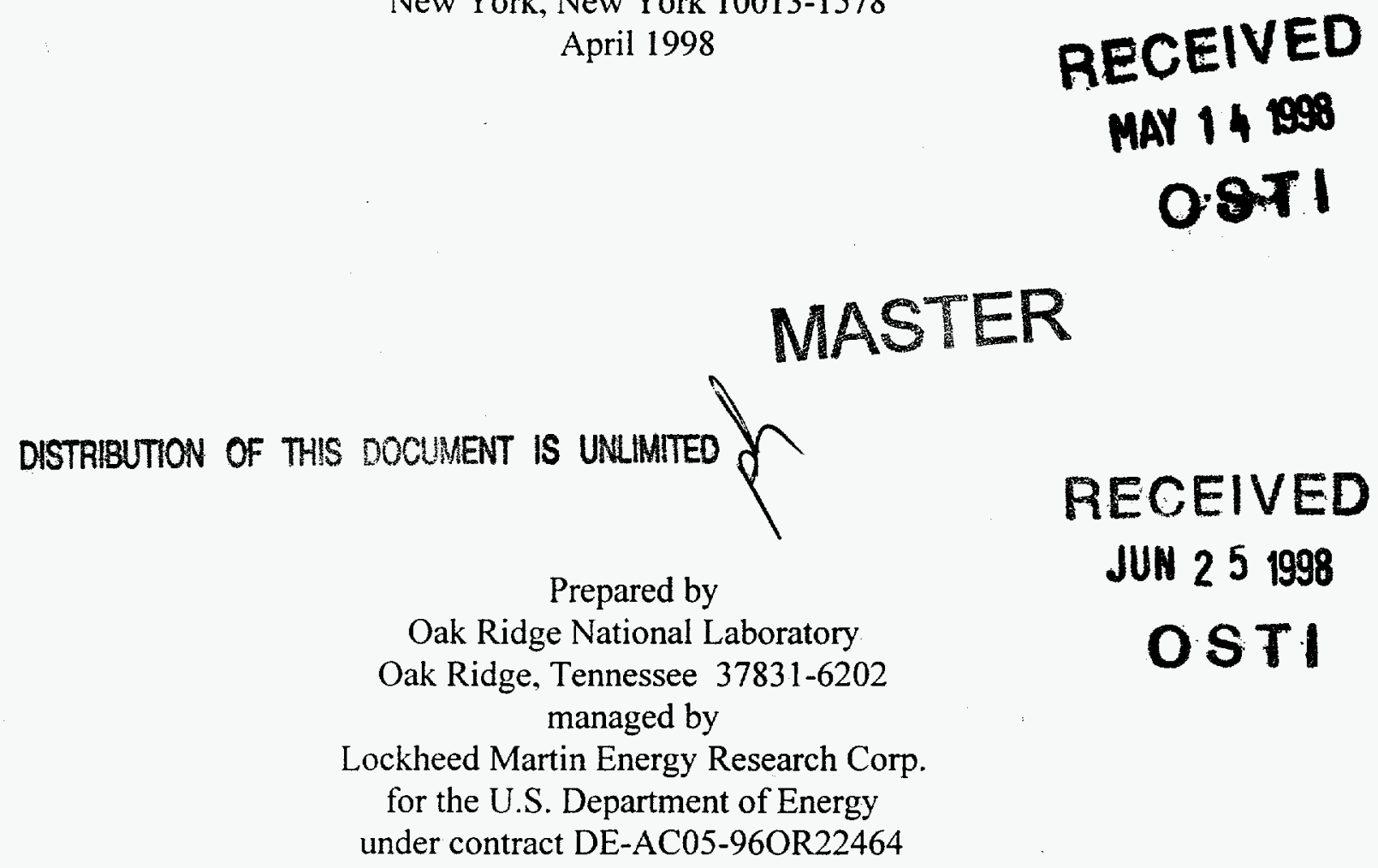


\section{DISCLAIMER}

This report was prepared as an account of work sponsored by an agency of the United States Government. Neither the United States Government nor any agency thereof, nor any of their employees, makes any warranty, express or implied, or assumes any legal liability or responsibility for the accuracy, completeness, or usefulness of any information, apparatus, product, or process disclosed, or represents that its use would not infringe privately owned rights. Reference herein to any specific commercial product, process, or service by trade name, trademark, manufacturer, or otherwise does not necessarily constitute or imply its endorsement, recommendation, or favoring by the United States Government or any agency thereof. The views and opinions of authors expressed herein do not necessarily state or reflect those of the United States Government or any agency thereof. 


\section{DISCLAIMER}

Portions of this document may be illegible electronic image products. Images are produced from the best available original document. 


\title{
GROUT AND VITRIFICATION FORMULA DEVELOPMENT FOR IMMOBILIZATION OF HAZARDOUS RADIOACTIVE TANK SLUDGES AT ORNL
}

\author{
T. Michael Gilliam and Roger D. Spence \\ Oak Ridge National Laboratory \\ P.O. Box 2008 \\ Oak Ridge, Tennessee 37831-6202
}

\section{INTRODUCTION}

Stabilization/solidification (S/S) has been identified as the preferred treatment option for hazardous radioactive sludges, and currently grouting and vitrification are considered the leading candidate S/S technologies. Consequently, a project was initiated at Oak Ridge National Laboratory (ORNL) to define composition envelopes, or operating windows, for acceptable grout and glass formulations containing Melton Valley Storage Tank (MVST) sludges. The resulting data are intended to be used as guidance for the eventual treatment of the MVST sludges by the government and/or private sector.

Wastewater at ORNL is collected, evaporated. and stored in the MVSTs pending treatment for disposal. The waste separates into two phases: sludge and supernate. The sludges in the tank bottoms have been accumulating for several years and contain a high amount of radioactivity, with some classified as transuranic (TRU) sludges. The available total constituent analysis for the MVST sludge indicates that the Resource and Conservation 
Recovery Act (RCRA) metal concentrations are high enough to be potentially RCRA hazardous; therefore, these sludges have the potential to be designated as mixed TRU waste. $\mathrm{S} / \mathrm{S}$ treatment must be performed to remove free liquids and reduce the leach rate of RCRA metals.

This paper focuses on initial results for the development of the operating window for vitrification. However, sufficient data on grouting are presented to allow a comparison of the two options.

\section{SURROGATE COMPOSITION}

In order to minimize costs and scheduling problems, initial formulation development experiments were conducted using a surrogate to represent the average composition of the tank sludge of interest. The composition of the MVST sludges and supernates was estimated using the available characterization data. ${ }^{1,2}$ The weighted average composition listed in Table 1 was obtained by taking into account the estimated mass of sludge in each tank to obtain an overall sludge composition if all of the sludges were mixed. This weighted average composition was the basis for the surrogate MVST sludge. As with the sludge, the weighted average composition for the supernate was obtained by using the quantity of supernate estimated for each tank. This weighted average forms the basis for the surrogate MVST supernate and is also shown in Table 1.

\section{VITRIFICATION}

Numerous glass families have been developed and evaluated on a commercial scale. Examples of these families include soda-lime-silicate (SLS), borosilicate, lead silicate, aluminosilicate, halide, borate, phosphate, sulfide, chalcogenide, chalcohalide, oxyhalide, oxynitride, and oxycarbide glasses. ${ }^{3-5}$ However, of these families, three have received the most attention for the vitrification of wastes. Consequently, these three (borosilicate, SLS, and phosphate) were the initial candidates for further study within this project. Many phosphate glasses are known to be readily attacked by water. ${ }^{4}$ Some have shown a tendency to be corrosive to melter refractory lining under normal operating conditions $s^{6.7}$ and, consequently, were discarded as a candidate for further study. Borosilicate glasses, which have been used extensively for immobilization of high-level radioactive wastes, have a large known immiscibility gap in the $\mathrm{CaO}-\mathrm{B}_{2} \mathrm{O}_{3}-\mathrm{SiO}_{2}$ system, ${ }^{8}$ and a high calcium content is a characteristic of the waste in this study. The known immiscibility leads to the strong probability of multiple 
Table 1. Tank waste and surrogate simulant composition.

\begin{tabular}{|c|c|c|c|c|c|c|}
\hline \multicolumn{2}{|c|}{ Tank Sludge } & \multicolumn{2}{|c|}{ Tank Supernate } & \multicolumn{3}{|c|}{ Surrogate Makeup } \\
\hline $\begin{array}{l}\text { Assumed } \\
\text { Species }\end{array}$ & $\begin{array}{l}\text { Composition } \\
\text { (wt \%) }\end{array}$ & Species & $\begin{array}{l}\text { Composition' } \\
(\mathrm{mg} / \mathrm{L})\end{array}$ & Compound & $\begin{array}{l}\text { Sludge } \\
\text { (wt \%) }\end{array}$ & $\begin{array}{l}\text { Supernate } \\
(\mathrm{mg} / \mathrm{L})\end{array}$ \\
\hline $\mathrm{Ag}_{2} \mathrm{O}$ & $0.0019 \%$ & $\mathrm{Ag}$ & 0.16 & $\mathrm{Ag}_{2} \mathrm{O}$ & 0.0019 & 0 \\
\hline $\mathrm{As}_{2} \mathrm{O}_{3}$ & $0.0060 \%$ & As & 0.56 & $\mathrm{Ba}(\mathrm{OH})_{2}$ & 0 & 7.25 \\
\hline $\mathrm{Ba}(\mathrm{OH})_{2}$ & $0.0073 \%$ & $\mathrm{Ba}$ & 5.81 & $\mathrm{CdO}$ & 0.0023 & 0.82 \\
\hline $\mathrm{CdO}$ & $0.0023 \%$ & $\mathrm{Cd}$ & 0.72 & $\mathrm{Na}_{2} \mathrm{Cr}_{2} \mathrm{O}_{7}$ & 0.0255 & 13.10 \\
\hline $\mathrm{Na}_{2} \mathrm{Cr}_{2} \mathrm{O}_{7}$ & $0.0255 \%$ & $\mathrm{Cr}$ & 5.20 & $\mathrm{HgCl}_{2}$ & 0.0040 & 0.46 \\
\hline $\mathrm{HgO}$ & $0.0032 \%$ & $\mathrm{Hg}$ & 0.34 & $\mathrm{PbO}$ & 0.0296 & 2.79 \\
\hline $\mathrm{NiO}$ & $0.0071 \%$ & $\mathrm{Ni}$ & 3.49 & $\mathrm{SeO}_{2}$ & 0.0066 & 0 \\
\hline $\mathrm{PbO}$ & $0.0296 \%$ & $\mathrm{~Pb}$ & 2.59 & $\mathrm{TINO}_{3}$ & 0.0021 & 22.39 \\
\hline $\mathrm{SeO}_{2}$ & $0.0066 \%$ & $\mathrm{Se}$ & 0.67 & $\mathrm{Al}(\mathrm{OH})_{3}$ & $0.99 \%$ & 0 \\
\hline $\mathrm{Tl}_{2} \mathrm{O}$ & $0.0017 \%$ & $\mathrm{Tl}$ & 17.18 & $\mathrm{CaCO}_{3}$ & $6.65 \%$ & 4109 \\
\hline $\mathrm{Al}_{2} \mathrm{O}_{3}$ & $0.65 \%$ & Al & 6 & $\mathrm{Ca}(\mathrm{OH})_{2}$ & $2.21 \%$ & 6780 \\
\hline $\mathrm{CaCO}_{3}$ & $6.65 \%$ & $\mathrm{Ca}$ & 5,313 & $\mathrm{Fe}_{2} \mathrm{O}_{3}$ & $0.20 \%$ & 0 \\
\hline $\mathrm{Ca}(\mathrm{OH})_{2}$ & $2.21 \%$ & $\mathrm{Fe}$ & 17 & $\mathrm{KNO}_{3}$ & $3.78 \%$ & 62695 \\
\hline $\mathrm{Fe}_{2} \mathrm{O}_{3}$ & $0.20 \%$ & $\mathrm{~K}$ & 24,247 & $\mathrm{MgCO}_{3}$ & $0.33 \%$ & 0 \\
\hline $\mathrm{KNO}_{3}$ & $3.78 \%$ & $\mathrm{Mg}$ & 938 & $\mathrm{Mg}(\mathrm{OH})_{2}$ & $1.82 \%$ & 2249 \\
\hline $\mathrm{MgCO}_{3}$ & $0.33 \%$ & $\mathrm{Na}$ & 89,373 & $\mathrm{NaNO}_{3}$ & $27.90 \%$ & 369782 \\
\hline $\mathrm{Mg}(\mathrm{OH})_{2}$ & $1.82 \%$ & Si & 30 & $\mathrm{NaBr}$ & $0.00 \%$ & 473 \\
\hline $\mathrm{NaNO}_{3}$ & $23.84 \%$ & $\mathrm{Sr}$ & 50 & $\mathrm{NaCl}$ & $0.43 \%$ & 7458 \\
\hline $\mathrm{NaCl}$ & $0.43 \%$ & Th & 10 & $\mathrm{NaF}$ & $0.14 \%$ & 2318 \\
\hline $\mathrm{NaF}$ & $0.14 \%$ & $\mathrm{U}$ & 169 & $\mathrm{Na}_{2} \mathrm{SO}_{4}$ & $0.27 \%$ & 3322 \\
\hline $\mathrm{Na}_{2} \mathrm{SO}_{4}$ & $0.27 \%$ & $\mathrm{CO}_{3}^{*}(\mathrm{IC})$ & 2,464 & $\mathrm{Sr}\left(\mathrm{NO}_{3}\right)_{2}$ & $0.04 \%$ & 0 \\
\hline $\mathrm{Sr}(\mathrm{OH})_{2}$ & $0.02 \%$ & Bromide & 367 & $\mathrm{Th}\left(\mathrm{NO}_{3}\right)_{4} \cdot 4 \mathrm{H}_{2} \mathrm{O}$ & $1.41 \%$ & 0 \\
\hline $\mathrm{ThO}_{2}$ & $0.68 \%$ & Chloride & 4,524 & $\mathrm{UO}_{2}\left(\mathrm{NO}_{3}\right)_{2} \cdot 6 \mathrm{H}_{2} \mathrm{O}$ & $2.44 \%$ & 0 \\
\hline $\mathrm{UO}_{2}$ & $1.31 \%$ & Fluoride & 1,049 & Total solids & $48.66 \%$ & NA \\
\hline TOC & $0.35 \%$ & Nitrate & 308,210 & Water & $51.34 \%$ & $N A$ \\
\hline Solids & $42.42 \%$ & Phosphate & 474 & $\mathrm{pH}$ & NA & 12 \\
\hline Water & $52.04 \%$ & Sulfate & 2,247 & & & \\
\hline Total & $94.46 \%$ & $\mathrm{pH}$ & 12 & & & \\
\hline
\end{tabular}

'Weighted average from MVST designated as W-21, W-31, and W-23 through W-28. 
glass phases within the resulting vitrified product. The unknown distribution coefficients between these phases of the contaminants of interest (both radionuclides and the RCRA metals) make a multiple-phase product undesirable. Consequently, the experimental study presented herein focused on the SLS system. The SLS system has been evaluated previously for numerous low-level radioactive and chemically hazardous (i.e., mixed) waste sludges ${ }^{9-11}$ and has the advantage of utilizing the calcium content of the waste as a needed additive.

Historically, the SLS system has used the three-component operating diagram with units of weight percent to illustrate regions of acceptable glass formulations. However, it is well known that the chemistry of any system occurs on a mole basis, rather than a weight basis. The primary reason that units of weight percent can successfully illustrate regions within the SLS system is that the molecular weights of the three components are so similar. The molecular weights of $\mathrm{Na}_{2} \mathrm{O}, \mathrm{CaO}$, and $\mathrm{SiO}_{2}$ are 62,56 , and $60 \mathrm{~g} / \mathrm{mol}$, respectively. Thus, a plot of composition in weight percent would accurately (to within a few percent error) reflect composition in mole percent. Obviously, as more components are introduced into the system, this comparison is no longer as accurate as the simple three-component system. Nonetheless, the operating diagram has proven to be an acceptable means of describing glass formulations containing mixed ${ }^{y-11}$ waste and is used herein.

The surrogate waste composition (on an oxide basis) is shown in the traditional ternary operating diagram in Figure 1. The "three" components represented on the diagram include alkalis (e.g., $\mathrm{Na}_{2} \mathrm{O}$ ), alkaline earths (e.g., $\left.\mathrm{CaO}\right)$, and glass formers $\left(\mathrm{SiO}_{2}\right.$ and $\left.\mathrm{Al}_{2} \mathrm{O}_{3}\right)$. Line A-A represents calculated bridging oxygens ${ }^{11}$ of $\sim 1$. Thus, line A-A is one of the boundaries of acceptable glass compositions and, in effect, represents the maximum allowable oxygen content in the melt for this application. Compositions to the right of line A-A are those with calculated bridging oxygens greater than 1 . The second boundary for acceptable glass compositions, also shown in Figure 1, is line B-B. Line B-B is particularly noteworthy, in that it represents a suspected phase-separation boundary based upon literature data for the $\mathrm{CaO}-\mathrm{Na}_{2} \mathrm{O}-\mathrm{SiO}_{2}$ system ${ }^{12}$ : that is, compositions beyond this boundary that are "deficient" in alkali and alkaline earth tend to form unary rather than ternary phases. Compositions to the right of line B-B would be expected to produce glass products characterized by phase separation and/or contained crystalline material. Line $\mathrm{C}-\mathrm{C}$ represents the maximum alkaline earth (RO) composition supplied by the waste. One of the constraints imposed is the assumption that the waste supplies one of the major SLS glass-forming-system components. thus necessitating only two additional additives. The resulting region, bounded by lines A-A. 


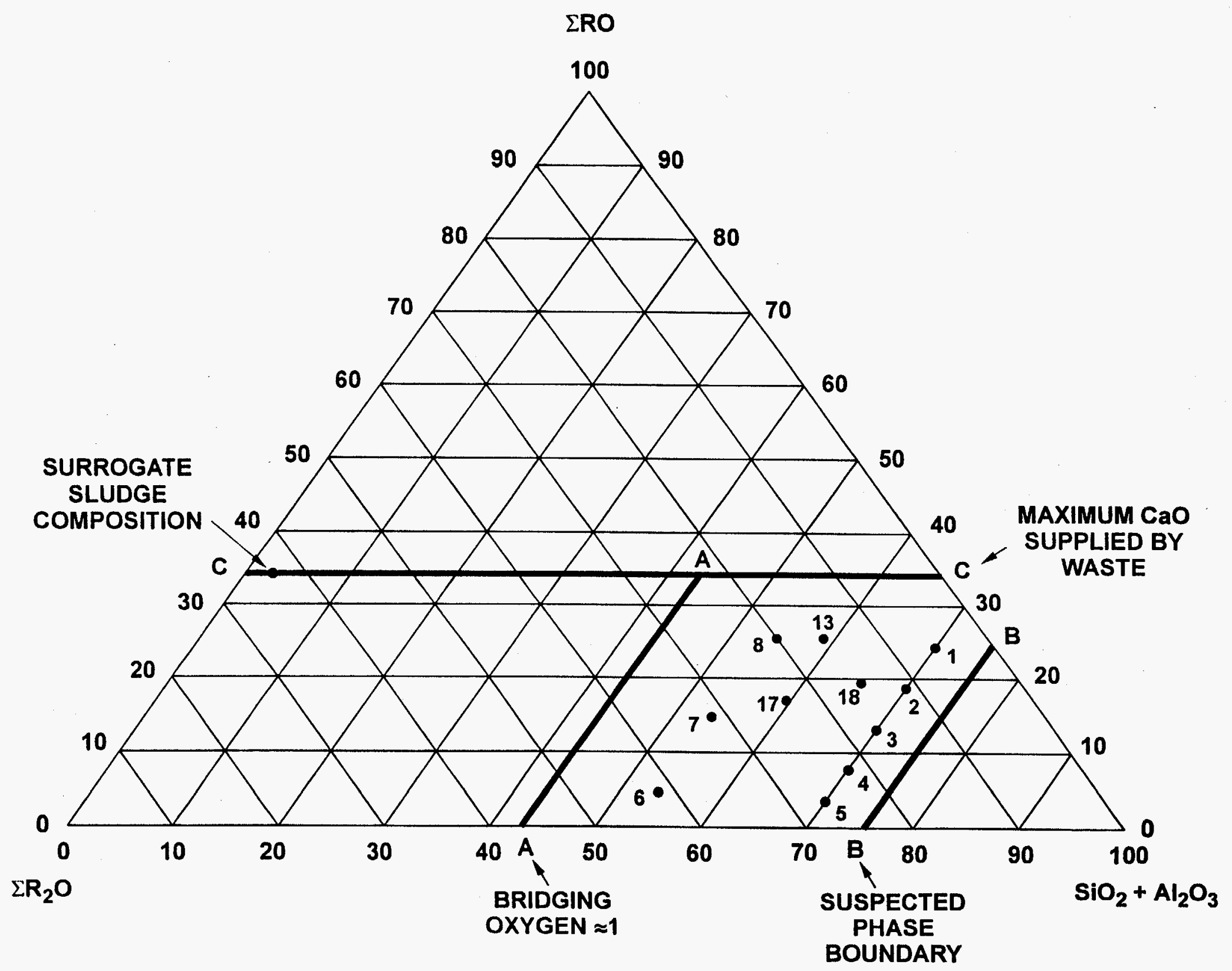

Figure 1. Operating diagram for soda-lime-silica glass containing MVST sludge. 
B-B, and C-C, represents the predicted region of acceptable compositions. The recipes or formulations for further evaluation are those additives that when combined with the waste, result in compositions within the bounded region.

It is interesting to note that the line $\mathrm{A}-\mathrm{A}$, representing a minimum bridging oxygen of $\sim 1$, corresponds to a waste loading of approximately $50 \mathrm{wt} \%$ (on an oxide basis). Therefore, for this glass-forming system and surrogate composition, $50 \mathrm{wt} \%$ represents the maximum achievable waste loading.

\section{Experimental Procedure}

A detailed discussion of the procedures in preparing glass is presented elsewhere. ${ }^{13} \mathrm{~A}$ brief summary of the procedure follows: The surrogate MVST sludge was prepared as shown in Table 1 without $\mathrm{HgCl}_{2}$ (as it would be volatilized at melt temperatures). The sludge was then dried at $105^{\circ} \mathrm{C}$ to a constant weight. The dried material was broken up with a hammer, followed by ball milling for approximately $2 \mathrm{~h}$. This dried, size-reduced material was passed through a $4.75-\mathrm{mm}$ sieve. This dried, homogenized, and sieved material then became the waste feed for the vitrification studies.

Weight loss observed upon drying was $52.4 \mathrm{wt} \%$. (The water content, including waters of hydration, of the surrogate sludge was $52.0 \mathrm{wt} \%$.) Homogenization of the dried material proved difficult due to the presence of a hard white crust on the upper surface of the dried waste. This white crust was determined to be $\mathrm{CaCO}_{3}$.

The recipe of interest was selected from the predicted composition region as described in Figure 1. The ingredients were weighed, combined, and rolled in a ball mill for approximately $30 \mathrm{~min}$. The material was then placed in a $99.8 \%$ pure $\alpha-\mathrm{Al}_{2} \mathrm{O}_{3}$ crucible with a loose-fitting lid. The crucible and contents were placed in a high-temperature furnace to achieve melting. The furnace was programmed to ramp to the desired melt temperature at $300^{\circ} \mathrm{C} / \mathrm{h}$ and hold at the melt temperature for $4 \mathrm{~h}$, after which time the fluid glass was poured into a stainless steel pan and allowed to cool to ambient temperature. The resulting solidified glass product was then subjected to various types of characterization and analyses.

\section{Experimental Results}

Glass recipes/formulations evaluated in the initial scoping tests and calculated composition of the resulting products are presented in Table 2. Select glass-product compositions are also shown on the traditional ternary diagram in Figure 1.

All glasses poured easily from the crucible, indicating that removal of the glass from fieldscale operations does not appear to be an issue of concern. Viscosity determinations (other 


\begin{tabular}{|c|c|c|c|c|c|c|c|c|c|c|c|}
\hline \multirow{2}{*}{\multicolumn{12}{|c|}{$\begin{array}{l}\text { Sontaining aried surrogate-sluage. } \\
\text { FORMULATI }\end{array}$}} \\
\hline \multirow{4}{*}{$\begin{array}{l}\text { Composition ID } \\
\text { grams waste } \\
\text { grams } \mathrm{Na}_{2} \mathrm{CO}_{3}\end{array}$} & & & 3 & & & & & & & & \\
\hline & 1 & 2 & 3 & 4 & 5 & 6 & 7 & 8 & 9 & 13 & 17 \\
\hline & 31.57 & 63.14 & 94.72 & 77.36 & 31.58 & 31.58 & 129.6 & 111.12 & 111.12 & 89.96 & 126.29 \\
\hline & 0 & 0 & 0 & 21.51 & 54.3 & 92.31 & 20.43 & 0 & 0 & 0 & 0 \\
\hline grams $\mathrm{CaCO}_{3}$ & $56.76^{\dagger}$ & 33 & 9.38 & 0 & 0 & 0 & 0 & 35.44 & 35.48 & 39.1 & 10.06 \\
\hline grams $\mathrm{SiO}_{2}$ & 103.25 & 101.55 & 99.76 & 100.69 & 103.25 & 81.01 & 76.48 & 77.37 & 77.37 & 85.38 & 84.37 \\
\hline Melt temperature C & 1400 & 1400 & 1400 & 1400 & 1400 & 1100 & 1100 & 1100 & 1200 & 1300 & 1300 \\
\hline \multicolumn{12}{|c|}{ CALCULATED PRODUCT COMPOSITION } \\
\hline $\mathrm{Ag}_{2} \mathrm{O}$ & 0.0008 & 0.001671 & 0.002507 & 0.002048 & 0.000836 & 0.000836 & 0.003431 & 0.002942 & 0.002942 & 0.002382 & 0.003343 \\
\hline $\mathrm{Al}_{2} \mathrm{O}_{3}$ & 0.2842 & 0.568352 & 0.852528 & 0.696231 & 0.284176 & 0.284176 & 1.166542 & 1.000299 & 1.000299 & 0.809902 & 1.136704 \\
\hline $\mathrm{CaO}$ & 23.5531 & 17.05726 & 10.62184 & 5.816238 & 2.373975 & 2.373975 & 9.745166 & 21.5805 & 21.59498 & 21.37322 & 13.24584 \\
\hline $\mathrm{CdO}$ & 0.0010 & 0.002026 & 0.003039 & 0.002482 & 0.001013 & 0.001013 & 0.004158 & 0.003565 & 0.003565 & 0.002887 & 0.004052 \\
\hline $\mathrm{Cr}_{2} \mathrm{O}_{3}$ & 0.0065 & 0.013026 & 0.019539 & 0.015957 & 0.006513 & 0.006513 & 0.026736 & 0.022926 & 0.022926 & 0.018562 & 0.026052 \\
\hline $\mathrm{Fe}_{2} \mathrm{O}_{3}$ & 0.0880 & 0.175991 & 0.263986 & 0.215589 & 0.087995 & 0.087995 & 0.361221 & 0.309744 & 0.309744 & 0.250787 & 0.351982 \\
\hline $\mathrm{K}_{2} \mathrm{O}$ & 0.7747 & 1.549404 & 2.324106 & 1.89802 & 0.774702 & 0.774702 & 3.180152 & 2.726951 & 2.726951 & 2.207901 & 3.098809 \\
\hline $\mathrm{MgO}$ & 0.6226 & 1.245242 & 1.867863 & 1.525421 & 0.622621 & 0.622621 & 2.555859 & 2.191626 & 2.191626 & 1.77447 & 2.490484 \\
\hline $\mathrm{Na}_{2} \mathrm{O}$ & 4.6774 & 9.354719 & 14.03208 & 19.84858 & 25.86484 & 40.69014 & 27.16711 & 16.46431 & 16.46431 & 13.33048 & 18.70944 \\
\hline $\mathrm{PbO}$ & 0.0130 & 0.02604 & 0.03906 & 0.031899 & 0.01302 & 0.01302 & 0.053447 & 0.04583 & 0.04583 & 0.037107 & 0.05208 \\
\hline $\mathrm{Sb}_{2} \mathrm{O}_{3}$ & 0.0001 & 0.000277 & 0.000415 & 0.000339 & 0.000138 & 0.000138 & 0.000568 & 0.000487 & 0.000487 & 0.000394 & 0.000553 \\
\hline $\mathrm{SeO}_{2}$ & 0.0029 & 0.005824 & 0.008736 & 0.007134 & 0.002912 & 0.002912 & 0.011954 & 0.01025 & 0.01025 & 0.008299 & 0.011648 \\
\hline $\mathrm{SiO}_{2}$ & 68.8209 & 67.69069 & 66.50008 & 67.11095 & 68.81252 & 53.98722 & 50.98345 & 51.57589 & 51.56141 & 56.89261 & 56.25006 \\
\hline Sro & 0.0072 & 0.014371 & 0.021557 & 0.017604 & 0.007186 & 0.007186 & 0.029496 & 0.025293 & 0.025293 & 0.020479 & 0.028742 \\
\hline $\mathrm{ThO}_{2}$ & 0.3373 & 0.674695 & 1.012042 & 0.826501 & 0.337347 & 0.337347 & 1.384811 & 1.187463 & 1.187463 & 0.96144 & 1.34939 \\
\hline $\mathrm{UO}_{3}$ & 0.6127 & 1.225448 & 1.838172 & 1.501174 & 0.612724 & 0.612724 & 2.515232 & 2.156788 & 2.156788 & 1.746263 & 2.450896 \\
\hline $\mathrm{Tl}_{2} \mathrm{O}$ & 0.0007 & 0.001494 & 0.002241 & 0.00183 & 0.000747 & 0.000747 & 0.003067 & 0.00263 & 0.00263 & 0.002129 & 0.002988 \\
\hline $\mathrm{SO}_{4}$ & 0.0798 & 0.159581 & 0.239371 & 0.195487 & 0.07979 & 0.07979 & 0.32754 & 0.280862 & 0.280862 & 0.227403 & 0.319162 \\
\hline $\mathrm{Cl}$ & 0.1169 & 0.23389 & 0.350835 & 0.286515 & 0.116945 & 0.116945 & 0.480059 & 0.411646 & 0.411646 & 0.333293 & 0.46778 \\
\hline $\begin{array}{l}\text { Waste loading \% } \\
\text { (oxide basis) }\end{array}$ & 10 & 20 & 30 & 25 & 10 & 10 & 41 & 35 & 35 & 29 & 40 \\
\hline
\end{tabular}


than by visual observation) were beyond the scope of this project. However, glass-viscosity models have been developed and can be used to qualitatively calculate the viscosity of the glass produced. ${ }^{14,15}$ All glass products evaluated in this study were deemed amorphous via $\mathrm{X}$-ray diffraction.

All glasses were subjected to Toxicity Characteristic Leach Procedure (TCLP) testing and were acceptable with respect to meeting RCRA Land Disposal Requirements (LDR) per this test: that is, none of the glasses produced would be designated as characteristically hazardous for $\mathrm{Ag}, \mathrm{As}, \mathrm{Ba}, \mathrm{Cd}, \mathrm{Cr}, \mathrm{Pb}$, or $\mathrm{Se}$. Thus, it is assumed that glasses with compositions within the region bounded by compositions from experiments numbered V-1, V-5, V-6, and V-8 would produce products with acceptable TCLP values.

It is widely recognized that leaching (or the release of constituents in a liquid environment) is a complex process that is impacted by leachant composition, available solid surface area, matrix composition, constituent speciation, anion associated with the constituent (i.e., chemical form of the constituent), soluble fraction of the constituent, and other factors. ${ }^{16}$ Nonetheless, the TCLP is the standard applied under RCRA. As stated previously, all glasses produced acceptable TCLP results as defined by the LDR. However, within this region of glass composition, TCLP concentrations actually varied significantly. For example, uranium leachate concentrations ranged from 0.039 to $8.5 \mathrm{mg} / \mathrm{L}$. Clearly, the TCLP, which is used to determine acceptable glass from a regulatory context, is not sufficient to identify and explain significant leaching differences at leachate concentrations below the regulatory threshold value.

Despite these concerns, the TCLP leach values can be used to identify qualitative trends with respect to TCLP leachate values versus glass composition. Experiments V-1 through V-5 represent glass compositions with an approximately constant waste loading and silica content (70 wt \%). The basic change in composition is that the $\mathrm{CaO}$ content is reduced, with a corresponding increase in $\mathrm{Na}_{2} \mathrm{O}$ content, as the experiment number is increased from $\mathrm{V}-1$ to V-5. As one would expect, both calcium and sodium leachate concentrations decreased, with their content in the glass. However, the potassium TCLP concentration steadily increased as the glass calcium content decreased, indicating that there may be a minimum $\mathrm{Ca} / \mathrm{Na}$ ratio necessary to significantly reduce leaching.

Runs V-6, V-7, and V-8 represent a similar series of runs with a constant silica content of approximately $55 \mathrm{wt} \%$. Leachate concentrations were generally higher for all constituents compared with glass compositions with $70 \mathrm{wt} \%$ silica. Clearly, silica, which is the basic 
' building block of the glass structure, is beneficial. It should be pointed out, however, that the line representing a silica content of $55 \mathrm{wt} \%$ corresponds to the compositions where calculated bridging oxygens are constant at 2 . At bridging oxygens of 2 , the basic glass structure changes from group silicates to ring or chain silicates. ${ }^{17}$ As bridging oxygens are increased, the structure further changes to layer silicates and ultimately to network silicates. ${ }^{17}$ In simplest terms, as the number of bridging oxygens increases, so does the bonding between the various silicate building blocks, thus producing a stronger glass matrix that should offer greater leach (or release) resistance. It is this trend with bridging oxygens that best describes the observed TCLP data.

Recorded visual observations during the pouring of the glasses made during the scouting studies are detailed elsewhere. ${ }^{13}$ In some cases, the glass was observed to have traveled up the crucible walls during the melting process. The presence of this thin layer, possibly indicating that foaming had occurred, could prove corrosive to melter components during actual full-scale operations. In essence, the glass is of low viscosity and can penetrate into the microcracks of the melter liner. This fluid melt is typically highly corrosive and can accelerate liner corrosion by this penetration. Consequently, it can significantly reduce the lifetime of a melter liner, thereby increasing cost and reducing operating time; in the worst case, it presents a safety hazard by corroding through the melter and allowing molten glass to flow out into the working environment. Unfortunately, there are few if any data on the increased rate of corrosion induced by this phenomena.

It is significant to note that this phenomena was observed for glass compositions with the highest waste loading. The high waste loading corresponds to glass melts with the highest nitrate content. Nitrates are known oxidants. Initially, it was assumed that the dominant decomposition products of the nitrate would be $\mathrm{NO}_{2}$ and $\mathrm{O}$, with the $\mathrm{O}$ combining with the cation to form its oxide. However, literature data have confirmed that to some extent the decomposition products are $\mathrm{N}_{2}$ and $\mathrm{O}_{2}$, as described by Volf. ${ }^{8}$

$$
\begin{gathered}
2 \mathrm{NaNO}_{3} \rightarrow 2 \mathrm{NaNO}_{2}+\mathrm{O}_{2} \\
4 \mathrm{NaNO}_{2} \rightarrow 2 \mathrm{Na}_{2} \mathrm{O}+2 \mathrm{~N}_{2}+3 \mathrm{O}_{2}
\end{gathered}
$$

The results. of these decomposition reactions are twofold. First, these reactions indicate the presence of more gas generation than anticipated from the nitrate salts. This "excess" of gas bubbling through the melt could lead to a lower melt viscosity than anticipated, and its release (escape) at the melt line could induce foaming. Second, the presence of this "excess" oxygen suggests that the melt chemistry takes place in the presence of more oxygen than envisioned 
in the bridging model that was used to calculate the expected range of acceptable compositions. This would lead to fewer bridging oxygens to form the cohesive glass structure, producing a less viscous (more fluid) melt. In simplest terms, the basic glass building block is the ionic bond between silicon $(\mathrm{Si})$ and oxygen $(\mathrm{O})$. The bridging oxygens, which connect the building blocks to form a durable structure, do so by covalent bonding between oxygens. In the presence of "excess" oxygen, ionic bonding is favored over covalent bonding and the glass does not form the structure predicted. This "lack of structure" leads to a fluid of lower viscosity than predicted.

Experience ${ }^{18-22}$ with borosilicate glasses developed for high-level radioactive wastes at Westinghouse Savannah River Company (WSRC) has shown that glass melt chemistry and behavior are strong functions of the oxidation-reduction (redox) equilibria, which are influenced by melt temperature and the presence of oxidizers such as nitrates or oxygen. In some cases, deoxygenation of salts can lead to foaming in waste-glass melters, particularly as melt temperature increases. In order to mitigate these concerns, it has been recommended that routine operation of borosilicate glass at a melter temperature of $1150^{\circ} \mathrm{C}$ be performed in melt conditions with oxygen fugacity maintained between $10^{-4}$ and $10^{-9}$ (or percent reduced iron between 20 and 80 ).

In order to verify that the melts in the scouting studies were being formed under "extreme" oxidizing conditions, the $\mathrm{Fe}^{2+} / \mathrm{Fe}^{\text {TOTAL }}$ redox couple was determined in the glass products. The method used was developed previously by WSRC in support of the high-level nuclear waste vitrification program. ${ }^{18-22}$ In essence the determination of the $\mathrm{Fe}^{2+} / \mathrm{Fe}^{3+}$ redox couple (or $\mathrm{Fe}^{2+} / \mathrm{Fe}^{\mathrm{TOTAL}}$ ) allows the calculation of the oxygen fugacity of the melt conditions. This, in turn, allows the determination of other inorganic redox couples using available electromotive force data.

Experiments numbered V-18, V-24, and V-25 represent replicates of the same recipe. Although the percent reduced iron for V-24 and V-25 showed excellent consistency ( 23 and $20 \%$, respectively), V-18 (11\%) did not. The differing values may be attributed to sample heterogeneity in spite of the efforts taken in sample preparation to achieve a homogeneous product. Conversely, it may be attributed to the accuracy/precision of the analytical technique at the low iron concentrations of this surrogate. In either case, comparisons of the relative percent reduced iron for the various samples must be assumed to be qualitative indicators rather than absolute values. 
In general, the iron redox data indicate oxidizing conditions, with the majority of the percent reduced iron values being in the teens or low $20 \mathrm{~s}$ (oxygen fugacity on the order of $10^{-4}$ and higher). Based upon the experience at WSRC, these values suggest that the melt is too oxidizing and conditions are favorable to observe foaming. For lack of additional data, the glass observed on the crucible walls above the melt line is assumed to result from foaming.

The iron redox data indicate that the melts experience "excessive" oxidizing conditions and suggest the need for the addition of a reductant to the melt. The role of the reductant would be to react with the "excess" oxygen, thereby mitigating its effect on the melt chemistry. Numerous reductants are available. In determining the reductant of choice, it is important to understand the chemistry of the nitrate decomposition. Nitrate salts such as $\mathrm{NaNO}_{3}$ and $\mathrm{KNO}_{3}$ melt at temperatures on the order of 300 to $350^{\circ} \mathrm{C}$, which is substantially below the melting point of the primary glass formers in the recipe. Although actual nitrate decomposition occurs over a range of temperatures, it is known to begin slightly above its melting temperature. ${ }^{8}$ Thus, the reduction reaction can and should take place at temperatures significantly below that of the melt temperature (operating temperature in field-scale operations). During field-scale operations, this would indicate that the reducing reaction should take place in the melter working space above the glass melt. The working space above the melt would experience a temperature gradient of feed temperature (near ambient) to that of the melt operating temperature. Consequently, the reduction reaction should take place at a temperature on the order of $400^{\circ} \mathrm{C}$ (slightly above the nitrate melt temperature). This would suggest introducing a reductant, perhaps as a second feed stream, into the working space above the melt in a regime of the desired temperature $\left(\sim 400^{\circ} \mathrm{C}\right)$. For reactions at this temperature, carbon-containing materials such as sugar appear to be a strong candidate.

\section{GROUT}

Cementitious $\mathrm{S} / \mathrm{S} /$ agents have been used for decades to treat hazardous and radioactive wastes. ${ }^{23.24}$ Agents used in treating wastes include cements (including portland and jet cements), lime, fly ash (both Class $\mathrm{F}$ and $\mathrm{C}$ ), ground-granulated blast furnace slag, sodium silicate, various clays, and additives and reagents too numerous to list, including several proprietary reagents. The stabilizing capabilities of Indian Red Pottery Clay (IRPC) for ${ }^{137} \mathrm{Cs}$ and of cement-fly ash for ${ }^{90} \mathrm{Sr}$ have been well established over the last three decades at ORNL. ${ }^{25-28}$ In addition, ground-granulated blast furnace slag has proven reducing capabilities ${ }^{29}$ to stabilize chromates and has demonstrated excellent stabilization of mercury in previously 
" unpublished work at ORNL. Bentonite, attapulgite, rice hull ash, and perlite were tested in dry blends for their ability to help prevent free-water formation, and perlite worked best for the grouts tested. Hence, the S/S agents chosen for this work were portland cement, Class F fly ash, ground-granulated blast furnace slag, perlite, and IRPC.

\section{Experimental Procedure.}

The dry blends mixed with the surrogate wet sludge to make grouts consisted of blends of two or more of the following dry powders: (1) ground-granulated blast furnace slag (slag) with a Blaine fineness of $6220 \mathrm{~cm}^{2} / \mathrm{g}$, (2) Type I-II portland cement (cement), (3) Class F fly ash (fly ash), (4) Grade H-200 perlite (perlite), (5) IRPC, (6) attapulgite 150 ground clay (attapulgite), and (7) bentonite clay (bentonite). The dry blends were processed for $2 \mathrm{~h}$ in an 8-qt twin-shell blender (or V-blender) from the Patterson-Kelley Co. The grouts were mixed in a Model N-50 Hobart mixer using a wire whip. The surrogate wet sludge was added to the Hobart bowl first; the dry blend was then added to the sludge while mixing on low speed (30-60 s). The grout was then mixed on low speed for $2 \mathrm{~min}$ and medium speed for $2 \mathrm{~min}$, cast into containers or molds for performance testing, and cured. The procedure for spiking with radionuclides for making leach samples consisted of adding the spike to the wet sludge in the Hobart bowl, mixing on low speed for $20 \mathrm{~min}$, and then adding the dry blend using the above procedure. The freshly made grout was stored in a humidity cabinet and cured in a humid environment at $30 \pm 1^{\circ} \mathrm{C}$. The samples were cured $7 \mathrm{~d}$.

\section{Experimental Results.}

The performance testing for the scope testing consisted of measuring the density, penetration resistance, free water (or bleed water), and TCLP performance after only $7 \mathrm{~d}$. The sensitivity testing consisted of measuring the density, 28-d unconfined compressive strength, 28-d free water, 28-d TCLP performance, and 28 -d leachability index of ${ }^{85} \mathrm{Sr}$ and ${ }^{137} \mathrm{Cs}$. A detailed discussion of results from the grout formulation development study is found elsewhere, ${ }^{13,30}$ and only a brief summary is presented here.

Initially grout recipes were used to establish the performance of two dry blends using no water-sorptive agents: (1) $83,0,9$, and $8 \mathrm{wt} \%$ and (2) $41,46,5$, and $8 \mathrm{wt} \%$ of slag, fly ash. cement, and IRPC. respectively. The first grouts established the water-demand nature of the surrogate sludge and blends. First, the dry blends were added to the wet sludge until the resulting grouts were too dry (wet sludge loadings of 37 and $33 \mathrm{wt} \%$ and water-to-solids ratio (W/S) of 0.24 and 0.21 , respectively, for these blends). Next, surrogate MVST supernate was added until the grouts were judged to be processable wet plastic masses. Prior work with 
* wastewater treatment sludges had obtained satisfactory performance with wet sludge loadings of $67 \mathrm{wt} \%$; therefore, these two dry blends were tested at this loading, and the free-water performance was tested over a range of W/S, using the surrogate supernate to adjust the W/S.

Results established that the W/S needs to be about 0.4 or more for the grout to be processable but that free water can be a problem above a W/S of 0.4 . Having no free water is a regulatory and waste acceptance criteria and a major driver for establishing the grout composition and an acceptable operating envelope. Consequently, the next series of grout recipes was devoted to testing water-sorptive agents in an attempt to control the bleed water and allow higher wet sludge loadings (in lieu of dewatering). These grouts were made with a constant amount of dry blend (wet sludge loading of $67 \mathrm{wt} \%$ and W/S of 0.53 ) and varying amounts of different water-sorptive agents in the dry blend, concentrating on dry blends with large amounts of fly ash (the traditional additive used to stabilize ${ }^{90} \mathrm{Sr}$ ). The water-sorptive agents tested were perlite, attapulgite, and bentonite. Perlite at $20 \mathrm{wt} \%$ in the dry blend resulted in the lowest free water after $7 \mathrm{~d}$ for these water-sorptive agents. This dry blend still resulted in significant free water at $7 \mathrm{~d}$, so increasing the cement content was tested to further reduce the free water (the dry blends contained $4 \mathrm{wt} \%$ cement to this point). The minimum free water was obtained with $20 \mathrm{wt} \%$ cement and $20 \mathrm{wt} \%$ perlite in the dry blend. This dry blend $(33,20,19,20$, and 8 wt \% of slag, cement, fly ash, perlite, and IRPC, respectively) was selected as the standard for further testing.

The last series of grout recipes in the scoping tests used this dry blend at wet sludge loadings ranging from 27 to $90 \mathrm{wt} \%$. Some free water occurred as the wet sludge loading exceeded $55 \mathrm{wt} \%$. Therefore, the grout loading for this sludge is limited to $55 \mathrm{wt} \%$, because of the free-water criteria, unless the wet sludge is dewatered prior to the grouting step. All of the grouts hardened, except at a wet sludge loading of $90 \mathrm{wt} \%$. The 7-d penetration resistance did decline significantly above wet sludge loadings of $60 \mathrm{wt} \%$. The grouts met the LDR TCLP requirements, and a significant number met the more stringent Universal Treatment Standards.

\section{SUMMARY}

An envelope, or operating window, for grout and glass compositions containing a surrogate MVST sludge was identified in support of the government and/or private sector treatment of the MVST sludges. Based on this work, the MVST sludges can be stabilized in either grout or glass for final disposal. Confirmation of these results with actual sludge samples must be 
- performed prior to final acceptance of either technique. The tank sludges can be stabilized in grout at a wet sludge loading of $55 \mathrm{wt} \%$, resulting in a volume increase of $40-50 \mathrm{vol} \%$ with little or no secondary waste generation. The high water content of the tank sludges limited the sludge loading to $55 \mathrm{wt} \%$, because higher loadings may result in free water in violation of the waste acceptance criteria of disposal facilities. Dewatering the sludge to $<52 \mathrm{wt} \%$ water prior to grouting may allow higher waste loadings, with correspondingly lower volume increases, without sacrificing TCLP performance or leach resistance. The grout strength does decline as the sludge loading increases above $60 \mathrm{wt} \%$, but a strong monolithic solid is not usually a waste acceptance criterion (although it does decrease the surface area available for leaching and consequently improves leach resistance). Waste glass logs are not annealed and subsequently fracture, leaving a high surface area available for leaching, but the superior leach resistance (leachability indexes ${ }^{23}>18$ compared to $>9$ for grout) of glass overcomes this problem. Grouts can stabilize the RCRA metals, including mercury, potentially a problem species for the tank sludges, and meet the LDR TCLP requirements. RCRA metals incorporated into the glass matrix are stabilized and leach resistant, but mercury is volatilized and must be treated in the off-gas.

The tank sludges can be stabilized in glass at a waste oxide loading of $40-50 \mathrm{wt} \%$, resulting in a net volume decrease of $50-60 \mathrm{vol} \%$. This is a threefold decrease in final waste form volume compared to grout, not counting the secondary waste generation volume from offgas treatment. The benefits of the lower glass volume compared to grout volume must be weighed against the generally higher capital and operating costs for vitrification, as well as the volume of secondary waste generated from both vitrification and grouting.

\section{REFERENCES}

1. M.B. Sears, J.L. Botts, R.N. Ceo, J.J. Ferrada, W.H. Griest, J.M. Keller, and R.L. Schenley, Sampling and Analysis of Radioactive Liquid Wastes and Sludges in the Melton Valley and Evaporator Facility Storage Tanks at ORNL, ORNL/TM-11652, Oak Ridge National Laboratory, Oak Ridge, Tenn. (September 1990).

2. V.L. Fowler, MVST Supernate Samples, Analytical Data, ORNL Internal Memorandum. Chemical Technology Division, Oak Ridge National Laboratory, Oak Ridge, Tenn. (April 5, 1995).

3. EPA Handbook on Vitrification Technologies for Treatment of Hazardous and Radioactive Waste, EPA/625/R-92/002, U.S. Environmental Protection Agency, Office of Research and Development. Washington, D.C. (May 1992).

4. A.K. Varshneya, Fundamentals of Inorganic Glasses, Academic Press, Inc., Harcourt Brace \& Company, San Diego (1994). 
- 5. A. Bleier, Evaluation of Final Waste Forms and Recommendations for Baseline Alternatives to Grout and Glass, ORNL/TM-13214, Oak Ridge National Laboratory, Oak Ridge, Tenn. (July 1997).

6. B.C. Sales and L.A. Boatner, Structural properties of lead-iron phosphate glasses, J. Non-Cryst. Solids, $71: 103$ (1985).

7. C.M. Jantzen, Investigation of Lead-Iron-Phosphate Glass for SRP Waste, DP-1729, Savannah River Laboratory, Aiken, S.C. (1986).

8. M.B. Volf, Chemical Approach to Glass, Glass Science and Technology 7, Elsevier, New York (1984).

9. C.M. Jantzen, N.D. Hutson, T.M. Gilliam, A. Bleier, and R.D. Spence, Vitrification Treatability Studies of Actual Waste Water Treatment Sludges, U.S. DOE Report WSRC-MS-95-0064, Savannah River Technology Center, Westinghouse Savannah River Co., Aiken, S.C., and Proceedings of Waste Management '95 (1995).

10. T.M. Gilliam et al., Vitrification of Wastewater Treatment Sludge. Volume II: Crucible-Scale Formulation Development Studies with Actual West End Treatment Facility Sludge Samples, ORNL/TM 13331, Oak Ridge National Laboratory, Lockheed Martin Energy Research Corporation, Oak Ridge, Tenn. (1998).

11. T.M. Gilliam and C.M. Jantzen, Waste vitrification: prediction of acceptable compositions in a limesoda-silica glass-forming system, in: Scientific Basis for Nuclear Waste Management, XX, Materials Research Society, Pittsburgh (1996).

12. E.M. Levin, C.R. Robbins, and H.F. McMurdie, Phase Equilibria Diagrams: Phase Diagrams for Ceramists, The American Ceramic Society, Waterville, Ohio (1992).

13. R.D. Spence and T.M. Gilliam, Grout and Glass Performance in Support of Stabilization/Solidification of the MVST Sludges, ORNL/TM-13616, Oak Ridge National Laboratory, Oak Ridge. Tenn. (in preparation).

14. C.M. Jantzen, Relationship of glass composition to glass viscosity, resistivity, liquidus temperature, and durability: first principles process-product models for vitrification of nuclear waste, Ceram. Trans. $23: 37(1991)$.

15. C.M. Jantzen and K.G. Brown. Statistical process control of glass manufactured for nuclear waste disposal, Am. Ceram. Soc. Bull. $72: 55$ (1993).

16. Final Report: Technical Resources Document on Solidification/Stabilization and its Application to Waste Materials, Rick Reduction Engineering Laboratory, U.S. Environmental Protection Agency, Cincinnati (1993).

17. W. Vogel, Chemistry of Glass, American Ceramic Society, Westerville, Ohio (1985).

18. H.D. Schreiber, C.W. Schreiber, M.W. Riethmiller and J.S. Downey, The effect of temperature on the redox constraints for the processing of high-level nuclear waste into a glass waste form, in: Scientific Basis for Nuclear Waste Management, XIII, V.M. Oversby and P.W. Brown, eds., Materials Research Society. Pittsburgh (1990).

19. M. J. Plodinec, Factors affecting the iron oxidation state and foaming in SRP waste glass, in:

Proceedings of the Symposium on High Temperature Materials Chemistry, D.D. Cubicciotti and D.L. Hildebrand eds., The Electrochemical Society, Pennington, N.J., (1982). 
20. M. J. Plodinec, Foaming During Vitrification of SRP Waste, U.S. DOE Report DPST-86-213, E.I. duPont deNemours \& Co., Savannah River Laboratory, Aiken, S.C. (January 1986).

21. H.D. Schreiber and A.L. Hockman, Redox chemistry in candidate glasses for nuclear waste immobilization, J. Am. Ceram. Soc. 70:591 (1987).

22. H.D. Schreiber, P.G. Leonhard, R.G. Nofsinger, M.W. Henning, C.W. Schreiber, and S.J. Kozak, Oxidation-reduction chemistry of nonmetals in a reference borosilicate melt, in: Advances in the Fusion of Glass, D.F. Bickford, W.E. Horsfall, F.E. Wooley, E.N. Boulos, J.N. Linscheit, F. Harding, F. Olix, W.C. LaCourse and L.D. Pye, eds., American Ceramic Society, Westerville, Ohio (1988).

23. R.D. Spence and T. M. Gilliam, Stabilization of mixed-waste tank sludges in glass and grout, in: Proceedings of American Chemical Society Emerging Technologies in Hazardous Waste Management LX, Pittsburgh ( September 15-17, 1997).

24. J. R. Conner, Chemical Fixation and Solidification of Hazardous Wastes, Van Nostrand Reinhold, New York (1990).

25. IAEA, Improved Cement Solidification of Low and Intermediate Level Radioactive Wastes, International Atomic Energy Agency, Technical Report Series No. 350, Vienna (1993).

26. E.W. McDaniel, T.M. Gilliam, and L.R. Dole, Oak Ridge National Laboratory, personal communication (April 15, 1984).

27. T.M. Gilliam, Leach testing of hydrofracture grouts containing hazardous waste, J. Underground Inj. Pract. Council l:192 (1986).

28. T.M. Gilliam and J.A. Loflin, Leachability Studies of Hydrofracture Grouts, ORNL/TM-9879, Oak Ridge National Laboratory, Oak Ridge, Tenn. (November 1986).

29. T.M. Gilliam, E.W. McDaniel, L.R. Dole, H.R. Friedman, J.A. Loflin, A.J. Mattus, I.L. Morgan, O.K. Tallent, and G.A. West, Summary Report on the Development of a Cement-Based Formula to Immobilize Hanford Facility Waste, ORNL/TM-10141, Oak Ridge National Laboratory, Oak Ridge, Tenn. (September 1986).

30. R.D. Spence, W.D. Bostick, E.W. McDaniel, T.M. Gilliam, J.L. Shoemaker, O.K. Tallent, I.L. Morgan, B.S. Evans-Brown, and K.E. Dodson, Immobilization of technetium in blast furnace slags, presented at the Third International Conference on the Use of Fly Ash, Silica Fume, Slag and Natural Pozzolans in Concrete, Trondheim, Norway (June 19-24. 1989). 